\title{
New Molecular, Biological, and Immunological Agents Inducing Hypophysitis
}

\author{
Anna Angelousi $^{\mathrm{a}} \quad$ Eleftherios Chatzellis ${ }^{\mathrm{b}}$ Gregory Kaltsas ${ }^{\mathrm{a}}$ \\ ${ }^{a}$ Sector of Endocrinology, Department of Pathophysiology, National University of Athens, and ${ }^{\mathrm{b}} 251 \mathrm{HAF}$ and VA \\ Hospital, Athens, Greece
}

\section{Keywords}

Anti-CTLA-4 antibodies - Programmed cell death protein-1 . Hypophysitis · Interferon · Cancer

\begin{abstract}
Hypophysitis is a relatively rare disease that exerts a strong autoimmune component encompassing different etiologies. Immunomodulatory drugs, such as interferon-a, are known to rarely induce hypophysitis. In recent years, a large number of new biological and immunomodulatory agents have been introduced into clinical practice. Although immune-suppressing agents used for the treatment of autoimmune disorders only rarely are associated with hypophysitis, it is commonly encountered with immunomodulatory agents used for the treatment of cancer. Hypophysitis related to anti-cytotoxic T-lymphocyte-associated antigen-4 antibodies (anti-CTLA-4 Abs) occurs with a prevalence ranging from 0 to $18 \%$ and is considered a distinctive side effect of anti-CTLA-4 Abs treatment. Hypophysitis due to the programmed cell death protein- 1 antibodies and their ligand is less common, its frequency ranging from 0 to $0.8 \%$. No cases of hypophysitis have been described with molecular targeted agents. Diagnosis of hypophysitis still remains clinical since anti-pituitary antibodies are not a sensitive marker and
\end{abstract}

\section{KARGER}

(C) 2017 S. Karger AG, Basel

E-Mail karger@karger.com

www.karger.com/nen thus its true prevalence is probably underestimated. The pathophysiology of hypophysitis induced by anticancer agents is not fully clarified. In most cases, treatment requires dose adjustment of the offending drug and pituitary hormone replacement. This mini-review aims to present currently available information regarding hypophysitis related to new molecular, biological, and immunological agents.

(c) 2017 S. Karger AG, Basel

\section{Introduction}

Hypophysitis is an inflammatory process of the pituitary gland that can be classified according to the anatomical areas of involvement (adenohypophysitis, infundibuloneurohypophysitis, or panhypophysitis) and/or its etiology (primary and secondary) (Table 1). The primary forms develop from intrinsic pathology of the pituitary gland, whereas the secondary ones are related to systemic diseases, infective processes, and/or pharmacological agents [1]. Histopathologically, primary hypophysitis is divided into 5 types: lymphocytic hypophysitis (LYH), granulomatous, xanthomatous, necrotizing, and IgG4 plasmacytic hypophysitis [2] (Table 1).

Anna Angelousi

Mikras Assias 75, Goudi

GR-11527, Athens (Greece)

E-Mail a.angelousi@gmail.com 
Table 1. Pathological classification of hypophysitis

\begin{tabular}{l}
\hline Types of hypophysitis \\
\hline Primary \\
Lymphocytic \\
Granulomatous \\
Xanthomatous \\
IgG4-related \\
Necrotizing \\
Mixed forms \\
\hline Secondary \\
Inflammatory \\
$\quad$ Sarcoidosis \\
Wegener granulomatosis vasculitis \\
Langerhans cell histiocytosis \\
Infectious \\
Tuberculosis \\
Syphilis \\
Fungi \\
Infiltrative \\
Hemochromatosis \\
Amyloidosis \\
Histiocytosis \\
Immunomodulatory drugs
\end{tabular}

The prevalence of primary hypophysitis is approximately $0.2-0.88 \%$ with an annual incidence of $1 / 9,000,000$ [2]. LYH constitutes $71.8 \%$ of all causes of primary hypophysitis [3, 4], and although it was thought to be strongly related to pregnancy $[5,6]$, it is also encountered in men and women having no relationship to pregnancy [79]. The diagnosis is confirmed by histopathology and detection of pituitary antibodies (Abs) in patients with isolated or multiple pituitary hormone deficiencies [4]. However, in most cases diagnosis is usually based on endocrinological and radiological findings in the relevant clinical setting $[10,11]$.

There has been some evidence in the past that medications affecting the immune system, such as interferon- $\alpha$ and interleukin, could lead to the development of hypophysitis $[12,13]$. Recent advances in the understanding of immunology and cancer biology have led to the development of new classes of immunomodulatory agents used for the treatment of autoimmune and malignant diseases. It is increasingly being recognized that new immune checkpoint therapies that inhibit the cytotoxic Tlymphocyte associated protein 4 (CTLA-4) and/or the programmed cell death protein-1 (PD-1) or its ligand (PD-L1) can induce hypophysitis [14-17]. Indeed, the National Cancer Institute has recommended a toxicity grading of adverse events including hypophysitis for patients treated with these agents (Table 2).

In this mini-review, we will provide information on currently used biological, molecular, and immunological agents that can lead to the development of hypophysitis in respect to its prevalence, presentation, and natural history, and explore the underlying pathogenic mechanism.

\section{Prevalence of Hypophysitis Related to Immunomodulatory and Anti-Inflammatory Agents Used for the Treatment of Autoimmune Diseases}

Adverse effects on endocrine organs have already been reported with the use of older immunomodulatory agents such as interferon- $\alpha$ and interleukins. Although interleukin-2 and interferon- $\alpha$ have well-described effects on thyroid autoimmunity and function [12], only relatively few cases of hypophysitis have been described in patients treated with either interferon alone $[12,13]$ or in association with ribavirin $[12,13,18-20]$. In the great majority of these cases, the symptoms and/or hormonal deficits of hypophysitis improved after immunotherapy interruption [18-20]. Cases of hypophysitis have also been reported with the more recent immunomodulatory agents used for the treatment of a number of autoimmune disorders, such as the anti-tumor necrosis factor alpha agent infliximab [21] and the monoclonal Ab rituximab [22] (against protein CD20, which is primarily found on the surface of immune system B cells) used for the treatment of a number of autoimmune diseases.

\section{Prevalence of Hypophysitis with Immune Checkpoint Inhibitors Used for Cancer Therapy}

Current immune checkpoint inhibitor therapies are based on stimulation of the negative immunoregulatory receptors on T-cell surface to enhance the host immunity against tumor cells. Immune checkpoint inhibitors are a new and effective class of cancer therapy, with a well-described mechanism of action (Fig. 1,2).

\section{Anti-Cytotoxic T-Lymphocyte-Associated Antigen-4 Abs}

Ipilimumab and tremelimumab are monoclonal IgG1 and IgG2 Abs respectively, directed against CTLA-4, a receptor expressed on $\mathrm{T}$ cells that exerts a suppressive effect on the immune response after T-cell/antigen-presenting cell interaction $[23,24]$. A number of studies have
Angelousi/Chatzellis/Kaltsas 
Table 2. Common terminology criteria for adverse events (CTCAE) grading system

\begin{tabular}{llll}
\hline & Grade 1 & Grade 2 & Grade 3 \\
\hline Pituitary & Asymptomatic or mild symptoms & Moderate & $\begin{array}{l}\text { Severe or medically significant but } \\
\text { not immediately life-threatening }\end{array}$ \\
\hline Management & $\begin{array}{l}\text { Clinical or diagnostic observations } \\
\text { only; intervention not indicated }\end{array}$ & $\begin{array}{l}\text { Minimal, local or noninvasive } \\
\text { intervention indicated; limiting } \\
\text { age-appropriate instrumental ADL }\end{array}$ & $\begin{array}{l}\text { Hospitalization or prolongation of } \\
\text { existing hospitalization indicated; } \\
\text { disabling; limiting self }\end{array}$ \\
\hline
\end{tabular}

Fig. 1. Immune checkpoint inhibitors, the CTLA-4 pathway. a The tumor-associated antigen is presented by the major histocompatibility complex (MHC) on the antigen-presenting cell (APC) and recognized by the T-cell receptor (TCR) of the T cell. Binding B7 on the APC cell with the CD28 receptor on the $\mathrm{T}$ cell is the second signal required for the activation of the $\mathrm{T}$-cell and the initiation of the immune response against the tumor cells. b CTLA-4 (cytotoxic T-lymphocyte-associated antigen-4) is a homolog of CD28 and limits proliferative response of activated T-cell competing with CD28 for ligand B7. This inhibition occurs in response to binding of $\mathrm{B} 7$ on $\mathrm{APC}$ with CTLA-4 receptor on the T cell and interrupts the second signal. c Anti-CTLA-4 antibodies block CTLA-4 and restore Tcell activation and proliferation.

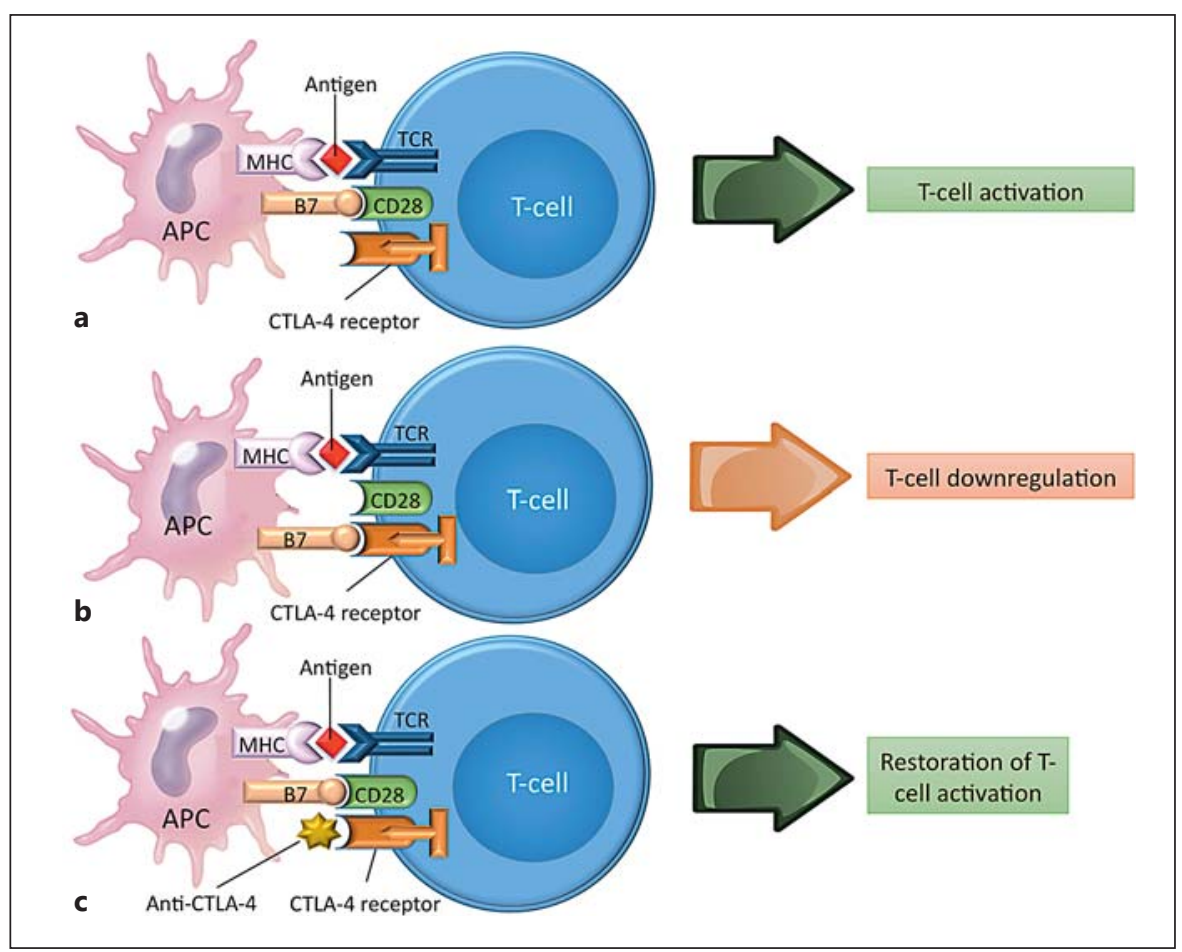

reported an approximately $1.5-18 \%$ prevalence of hypophysitis in patients treated with ipilimumab [25-37] and a $0.4-2 \%$ with tremelimumab [38-40]; however, this prevalence varied largely among different studies. This is mainly due to the fact that although in the approved protocol the dose of ipilimumab is $3 \mathrm{mg} / \mathrm{kg}$ administered as an i.v. infusion every 3 weeks for a total of 4 doses, in some patients, maintenance therapy may continue with additional infusions at longer time intervals [41]. Additionally, the follow-up of the different studies ranged from few months [41] up to several years [31]. In a recent metaanalysis, it was concluded that hypophysitis due to monotherapy with ipilimumab or tremelimumab is encountered in $2.6 \%$ of cases [42].

Hypophysitis Secondary to Biological Therapies
In contrast to conventional LYH that is reported more commonly in females, ipilimumab-related autoimmune hypophysitis is more common in males $[16,28,29]$. Most patients developed hypophysitis after having received a 3 $\mathrm{mg} / \mathrm{kg}$ dose of ipilimumab and became symptomatic approximately 11 weeks after treatment [43]. Although the risk of other endocrine-related adverts events, such as thyroid diseases, after taking ipilimumab appears to be dose-dependent $[31,32,44]$, in the case of hypophysitis, data are less clear. According to recent studies, higher dosages of ipilimumab (10 vs. $3 \mathrm{mg} / \mathrm{kg}$ ), may increase the risk of hypophysitis $[16,27,32]$. However, in most protocols ipilimumab dosages were escalated rapidly, and hypophysitis typically occurred after several cycles of treatment regardless of the dose administered [32]. Thus, in

Neuroendocrinology 2018;106:89-100 91 
Fig. 2. Immune checkpoint inhibitors, the PD-1 pathway. PD-1 is an immune cellspecific surface receptor, and ligands for PD-1 (PD-L1 and PD-L2) are associated proteins that are found on antigen-presenting cells and cancer cells. When bound to a ligand, PD-1 lowers the threshold for apoptosis, induces anergy via blunted $T$ cell receptor signaling and generally leads to $\mathrm{T}$ cell depletion. a In certain tumor cells, upregulation of $\mathrm{PD}-\mathrm{L} 1$ expression has been observed, which leads to increased inhibition of $\mathrm{T}$ cell activity in favor of tumor cell survival. b A monoclonal antibody against PD-1 can block this pathway and result in upregulation of immune response and inhibition of tumor growth.

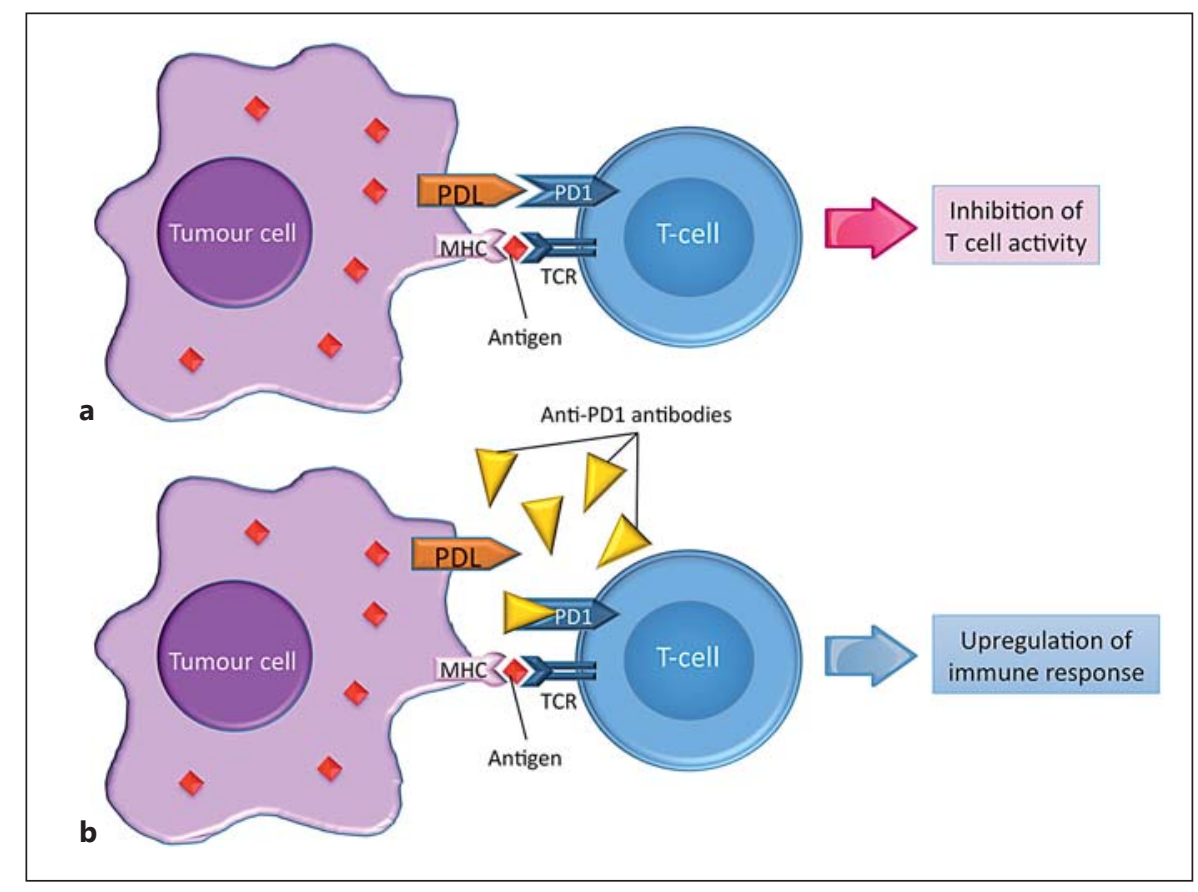

contrast to previous analyses and trials showing that antiCTLA-4-induced hypophysitis may be dose related, a recent meta-analysis found no dose-effect relationship following ipilimumab administration and any of the endocrine-related side effects including hypophysitis [15].

Interestingly, hypophysitis was not reported in patients treated with ipilimumab who had been pre-treated with chemotherapy or radiotherapy, suggesting that the immune cell depletion induced by these treatments may have prevented the development of hypophysitis [16].

\section{Anti-Programmed Cell Death Protein-1 Abs and Their Ligand}

Nivolumumab and pembrolizumab are IgG4 Abs against the $\mathrm{PD}-1$ protein that have demonstrated efficacy in patients with advanced melanoma, renal cell carcinoma, and non-small lung cancer $[24,45]$. The prevalence of hypophysitis is relatively lower, less than $1 \%$, with these agents compared to anti-cytotoxic T-lymphocyte-associated antigen-4 Abs (anti-CTLA-4 Abs) (Table 3) [45-52]. Two meta-analyses confirmed these results and concluded that the overall prevalence of anti-programmed cell death protein-1 Abs (anti-PD-1 Abs)-induced hypophysitis ranges between 0.2 and $0.8 \%[14,53]$.

The time of onset of nivolumab-induced hypophysitis was 5.5 months (range: 1.6-11 months) and of pembrolizumab 3.3-3.7 months (range: 1 day to 7.2 months) [14, 53]. Up to date, no cases of pituitary dysfunction have been reported in trials evaluating atezolizumab [54], an IgG1 anti-PD-L1 monoclonal Ab in patients treated for cancer, as well as with BMS-936559 another anti-PD-L1 $\mathrm{Ab}$ used as antiretroviral treatment in HIV patients [55].

\section{Comparison of Monotherapy with Anti-CTLA-4 versus Anti-PD-1 Abs and of Either Immune Checkpoint Inhibitor with Chemotherapy}

A recent study comparing pembrolizumab versus ipilimumab in patients with advanced melanoma showed a higher prevalence of hypophysitis in the ipilimumabtreated patients, whereas the prevalence of other endocrinopathies such as hypothyroidism and hyperthyroidism was higher in the pembrolizumab-treated patients [49]. According to a meta-analysis, monotherapy with antiPD-1 (nivolumab or pembrolizumab) exhibited an even lower risk for hypophysitis ( $\mathrm{RR}=0.148$ [95\% CI: 0.040.5]) compared to ipilimumab [14].

In one study, monotherapy with pembrolizumab was associated with hypophysitis in $0.4 \%$ of the cases and only in those who received a $10 \mathrm{mg} / \mathrm{kg}$ dose, whereas no case was described in the chemotherapy group [46]. In another trial, monotherapy with pembrolizumab at any dose (either with 2 or $10 \mathrm{mg} / \mathrm{kg}$ ) did not show an increased risk for hypophysitis $(<1 \%)$ when compared with docetaxel [47]. Monotherapy with tremelimumab was associated with hypophysitis in $1.8 \%$ of cases compared to none in the chemotherapy group [39].
Angelousi/Chatzellis/Kaltsas 
Table 3. Prevalence of hypophysitis with immunomodulatory agents anti-CTLA-4 and PD-1

\begin{tabular}{|c|c|c|c|c|}
\hline Agents [Ref.] & $\begin{array}{l}\text { Type of the } \\
\text { study (phase) }\end{array}$ & Dose of agent & Patients, $n$ & Prevalence \\
\hline \multicolumn{5}{|l|}{ Anti-PD-1 } \\
\hline $\begin{array}{l}\text { Pembrolizumab vs. } \\
\text { chemotherapy }^{\mathrm{a}}[46]\end{array}$ & 2 & 2 or $10 \mathrm{mg} / \mathrm{kg}$ & $\begin{array}{l}540 \text { with ipilimumab-refractory } \\
\text { melanoma }\end{array}$ & $0.4 \%$ in $10 \mathrm{mg} / \mathrm{kg}$ (grade 3,4 ) \\
\hline $\begin{array}{l}\text { Pembrolizumab vs. } \\
\text { docetaxel [47] }\end{array}$ & 3 & 2 vs. $10 \mathrm{mg} / \mathrm{kg}$ & $\begin{array}{l}339 \text { vs. } 343 \text { with advanced } \\
\text { NSCLC }\end{array}$ & $<1 \%$ in both doses \\
\hline Pembrolizumab [48] & 1 & 2 or $10 \mathrm{mg} / \mathrm{kg}$ & $\begin{array}{l}173 \text { with ipilimumab-refractory } \\
\text { advanced melanoma }\end{array}$ & $0.6 \%$ (grade 3,4 ) vs. $0 \%$ \\
\hline $\begin{array}{l}\text { Pembrolizumab vs. } \\
\text { ipilimumab [49] }\end{array}$ & 3 & 3 vs. $10 \mathrm{mg} / \mathrm{kg}$ & $\begin{array}{l}555 \text { vs. } 256 \text { with advanced } \\
\text { melanoma }\end{array}$ & $\begin{array}{l}0.4-0.7 \%(0.4 \% \text { grade } 3,4) \text { vs. } \\
2.3 \%(1.6 \% \text { grade } 3,4)\end{array}$ \\
\hline Pembrolizumab [50] & 3 & 2 or $10 \mathrm{mg} / \mathrm{kg}$ & $\begin{array}{l}655 \text { with advanced melanoma } \\
\text { ipilimumab refractory or naïve } \\
\text { treatment }\end{array}$ & $0.5 \%(0.15 \%$ grade 3,4$)$ \\
\hline Pembrolizumab [51] & 2 & $10 \mathrm{mg} / \mathrm{kg}$ & $\begin{array}{l}41 \text { patients with progressive } \\
\text { metastatic carcinoma with or } \\
\text { without mismatch-repair } \\
\text { deficiency }\end{array}$ & $\begin{array}{l}10 \% \text { (including also thyroiditis, } \\
\text { hypothyroidism) }\end{array}$ \\
\hline Nivolumumab [45] & 1 & $0.1-10 \mathrm{mg} / \mathrm{kg}$ & $\begin{array}{l}296 \text { with advanced melanoma, } \\
\text { NSCLC, castration-resistant } \\
\text { prostate cancer, or renal-cell or } \\
\text { colorectal cancer }\end{array}$ & $<1 \%$ \\
\hline Nivolumumab [52] & 1 & $0.1-1.0 \mathrm{mg} / \mathrm{kg}$ & 107 with advanced melanoma & $1 \%$ \\
\hline \multicolumn{5}{|l|}{ Anti-CTLA-4 } \\
\hline Ipilimumab [25] & 3 & $3 \mathrm{mg} / \mathrm{kg}$ & 131with metastatic melanoma & $1.5 \%$ (grade 3$)$ \\
\hline Ipilimumab [26] & Retrospective & $3 \mathrm{mg} / \mathrm{kg}$ & 298 with metastatic melanoma & $5.7 \%(3.3 \%$ grade 3,4$)$ \\
\hline Ipilimumab [27] & 3 & $10 \mathrm{mg} / \mathrm{kg}$ & 471 with stage III melanoma & $18 \%(5 \%$ grade 3,4$)$ \\
\hline Ipilimumab [28] & Retrospective & 3 vs. $10 \mathrm{mg} / \mathrm{kg}$ & 211 with advanced melanoma & Overall $8 \%$ ( 8 vs. $10 \%)$ \\
\hline Ipilimumab [29] & Retrospective & 3 vs. $10 \mathrm{mg} / \mathrm{kg}$ & 187 with metastatic melanoma & Overall $13.3 \%$ (9 vs. $4 \%$ ) \\
\hline Ipilimumab [30] & Retrospective & 3 vs. $10 \mathrm{mg} / \mathrm{kg}$ & 154 with metastatic melanoma & Overall $11 \%$ (8 vs. $3 \%$ ) \\
\hline Ipilimumab [31] & Retrospective & 3 vs. $10 \mathrm{mg} / \mathrm{kg}$ & 131 with advanced melanoma & $11.5 \%$ (3 vs. $8 \%)$ \\
\hline Ipilimumab [32] & $1-2$ & $3-9 \mathrm{mg} / \mathrm{kg}$ & 46 with metastatic melanoma & Overall 17\% (grade 3,4 ) \\
\hline Ipilimumab [33] & 2 & $3 \mathrm{mg} / \mathrm{kg}$ & $\begin{array}{l}163 \text { with metastatic melanoma } \\
\text { and renal cancer }\end{array}$ & $5 \%($ grade 3,4$)$ \\
\hline Ipilimumab [34] & 2 & $3 \mathrm{mg} / \mathrm{kg}$ & $\begin{array}{l}27 \text { with locally advanced or } \\
\text { metastatic pancreatic } \\
\text { adenocarcinoma }\end{array}$ & $3.7 \%$ (grade 3,4$)$ \\
\hline Ipilimumab [35] & 2 & $3 \mathrm{mg} / \mathrm{kg}$ & $\begin{array}{l}61 \text { with metastatic renal cell } \\
\text { cancer }\end{array}$ & $3.3 \%$ (grade 3,4$)$ \\
\hline Ipilimumab [36] & 1 & $3 \mathrm{mg} / \mathrm{kg}$ & $\begin{array}{l}18 \text { with non-Hodgkin } \\
\text { lymphoma }\end{array}$ & $6 \%$ (grade 1,2$)$ \\
\hline Ipilimumab [37] & 2 & $10 \mathrm{mg} / \mathrm{kg}$ & 53 with advanced melanoma & $4 \%$ (grade 2,3$)$ \\
\hline Tremelimumab [38] & 2 & $15 \mathrm{mg} / \mathrm{kg}$ & $\begin{array}{l}251 \text { with advanced refractory or } \\
\text { relapsed melanoma }\end{array}$ & $0.4 \%(0.4 \%$ grade 3,4$)$ \\
\hline $\begin{array}{l}\text { Tremelimumab vs. } \\
\text { chemotherapy [39] }\end{array}$ & 3 & $15 \mathrm{mg} / \mathrm{kg}$ & 328 with advanced melanoma & 2 vs. $0 \%$ \\
\hline $\begin{array}{l}\text { Tremelimumab vs. } \\
\text { chemotherapy [40] }\end{array}$ & 1 & $0.01-15 \mathrm{mg} / \mathrm{kg}$ & 39 with solid tumors & $2.5 \%$ in $15 \mathrm{mg} / \mathrm{kg}$ (grade 2 ) \\
\hline $\begin{array}{l}\text { Combinations } \\
\text { Ipilimumab + } \\
\text { nivolumumab [44] }\end{array}$ & 1 & $\begin{array}{l}0.3-10 \mathrm{mg} / \mathrm{kg}+ \\
1-10 \mathrm{mg} / \mathrm{kg}\end{array}$ & 86 with advanced melanoma & Overall: $4 \%(2 \%$ grade 3,4$)$ \\
\hline $\begin{array}{l}\text { Ipilimumab + } \\
\text { nivolumumab [60] }\end{array}$ & 3 & $\begin{array}{l}3 \mathrm{mg} / \mathrm{kg}+ \\
3 \mathrm{mg} / \mathrm{kg}\end{array}$ & 314 with melanoma & $\begin{array}{l}\text { Overall: } 7.7 \%(1.6 \% \text { grade } 3,4) \\
\text { (nivolumab: } 0.6 \% \text { [0.3\% grade } \\
\text { 3/4], ipilimumab: } 4 \% \text { [ } 2 \% \text {, grade } \\
3,4] \text { ) }\end{array}$ \\
\hline
\end{tabular}

Hypophysitis Secondary to Biological 
Table 3 (continued)

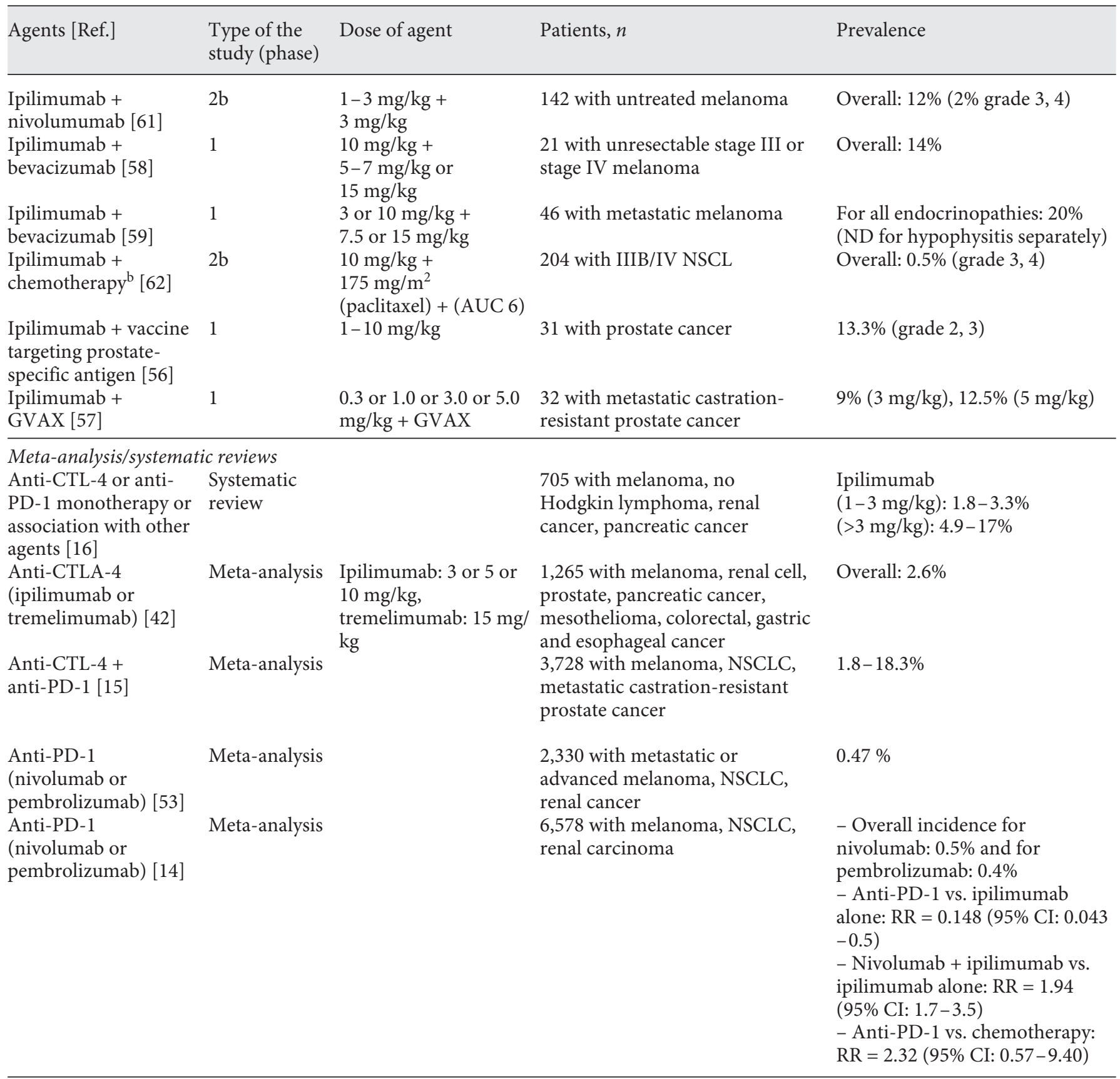

PD-1, programmed death 1; NSCLC; non-small-cell lung cancer; anti-CTLA-4, anti-cytotoxic T-lymphocyte antigen-4; ND, no data; GVAX, granulocyte-macrophage colony-stimulating factor-transduced allogeneic prostate cancer cells vaccine. ${ }^{a}$ Paclitaxel plus carboplatin, paclitaxel, carboplatin, dacarbazine, or oral temozolomide. ${ }^{\mathrm{b}}$ Paclitaxel and carboplatin. 
Association of Immune Checkpoint Inhibitors with

Adjuvant Therapies

The prevalence of hypophysitis varied significantly depending on the use of adjuvant therapy [16]. In patients receiving ipilimumab with adjuvant therapy, such as prostate-specific antigen vaccine [56], prostatic cancer cell vaccine (GVAX) [57], or the anti-vascular endothelial growth factor bevacizumab $[16,58,59]$, the prevalence of hypophysitis ranged between 9 and $14 \%$. In patients receiving the combination of nivolumab with ipilimumab, the prevalence varied between 4 and $12 \%[45,60,61]$. Overall, the combination of nivolumab with ipilimumab exhibited an increased risk for hypophysitis compared to ipilimumab alone ( $\mathrm{RR}=1.94$ [95\% CI: 1.7-3.5]) [14]. In contrast, the coadministration of ipilimumab with various chemotherapeutic agents, including Taxol, carboplatin, dacarbazine, and fotemustine $[58,59,62,63]$, or other anticancer-targeted agents, such as vemurafenib, and dabrafenib [64], did not increase the prevalence of hypophysitis compared to monotherapy with ipilimumab alone [64]. Overall, a recent meta-analysis revealed that the prevalence of autoimmune hypophysitis due to treatment of ipilimumab at lower doses $(1-3 \mathrm{mg} / \mathrm{kg})$ in combination with vaccination was associated with hypophysitis in $9 \%$ of cases, whereas higher doses of ipilimumab (5 mg/kg) were associated with hypophysitis in $13.3 \%$ of cases.

\section{Potential Pathogenic Mechanisms}

The precise mechanisms by which immune checkpoint inhibitors cause hypophysitis remain unclear. An immune-mediated pathogenesis has recently been supported following the detection of anti-thyrotroph, anticorticotroph, and anti-gonadotroph Abs in patients' serum [65]. Histopathologically, a distinct infiltration with mononuclear cells found in the pituitary gland, but not in other organs, suggests that these mechanisms may be specific to the pituitary gland [65]. The fact that anti-CTLA-4 agents can stimulate de novo pituitary-reactive effector $\mathrm{T}$ cells, while anti-PD-1 therapy is not involved in initial Tcell activation could explain the lower occurrence of PD1-induced hypophysitis (Fig. 1) [66]. The pituitary gland may express CTLA-4, making it a direct target for antiCTLA-4 Abs [65] leading to the activation of Ab-dependent cell-mediated cytotoxicity by direct binding to pituitary cells [65-68]. In particular, a type 2 hypersensitivity reaction has been proposed as a cause of damage to the pituitary gland. Upon administration of ipilimumab, immune complexes are formed in the pituitary containing CTLA- 4 antigen and CTLA- 4 Ab inducing an activation of the classical complement cascade [65].

Hypophysitis Secondary to Biological Therapies
As already mentioned, the difference in the prevalence of hypophysitis induced by the various immunomodulatory agents may be related to their mode of action as antiCTLA-4 Abs and anti-PD-1 Abs target different pathways (Fig. 1). CTLA-4 is involved in initial T-cell deactivation, whereas PD-1 targets the modulatory phase of the immune response [69]. In an active immune response, $\mathrm{CD} 28$ on the T-cell surface binds to the B7 costimulatory ligand on antigen-presenting cells resulting in the T-cell activation that leads to the translocation of CTLA- 4 to the plasma membrane. CTLA-4 binds with high affinity to B7 and can compete with CD28 to further inhibit T-cell activity. Thus, the binding of anti-CTLA-4 Abs, such as ipilimumab, to CTLA- 4 prevents B7 binding and the upregulation of T-cell activity [70].

PD-1 modulates the immune response in a more peripheral way primarily at the tumor microenvironment. PD-1 is expressed on the surface of activated T- and Blymphocytes and monocytes and inhibits the immune response of these cells through interaction with its ligand PD-L1 (Fig. 2). PD-1 is upregulated by tumor cells and facilitates the escape of tumors from immune surveillance [71]. Patients treated with PD-1 and/or PD-L1 Abs, which are IgG4 Abs, in contrast to ipilimumab, which is an IgG1 $\mathrm{Ab}$, develop hypophysitis less frequently [72]. This implies that IgG1, which activates the classic complement pathway, might be a possible mechanism of anti-CTLA4-related hypophysitis [66]. Furthermore, there are differences in the mode of action between PD-1 and PD-L1 Abs. PD-L1 also binds to CD80 in addition to its interaction with PD-1 receptors on activated T cells. This complex setting of ligand-receptor interactions by PD-1 and PD-L1 might account for the differences in incidence of endocrine-related adverse effects [73].

Genetic factors predisposing to immune checkpointinduced hypophysitis could also be implicated [74]. Polymorphisms in the CTLA-4 or PD-1 gene have been shown to be associated with a higher incidence of autoimmune disorders including hypophysitis. As a result, the role of human CTLA-4 germline mutations in triggering autoimmune disease and the immune checkpoint inhibitor-induced hypophysitis is currently under investigation [74].

Hypophysitis attributable to Abs targeting immune mediators, such as tumor necrosis factor alpha or interleukins, used in patients with autoimmune diseases are relatively rare, and only scarce case reports exist. This might be explained by the inherent mechanism of action of these Abs that aim at reducing rather than enhancing the immune activation triggering the disease [17]. In contrast, anti-CTLA-4 Abs, by releasing one of the molecules

Neuroendocrinology 2018;106:89-100 DOI: $10.1159 / 000480086$ 
involved both in cancer immune escape and autoregulatory activity of the immune response, induce not only tumor response but also autoimmune endocrine-related adverse events [17].

\section{Future Directions on Drug-Induced Hypophysitis}

The role of genetic alterations in the pathogenesis of hypophysitis and their usefulness as predictive factors for disease course are under investigation. Tumor mutational load seems to predict efficacy and overall survival in patients receiving ipilimumab. Specifically, de novo somatic mutations of the tumor leading to the production of proteins recognized by the immune system as non-self, may serve as a prognostic marker for treatment efficacy and overall survival in patients receiving ipilimumab, although such an event alone it is not sufficient to induce a clinical benefit [75]. Indeed, there are somatic neoepitopes detected in patients who have experienced a prolonged benefit following treatment with these agents, whereas they are absent in those without such a clinical benefit [75]. Two recent studies identified individuals with germline CTLA-4 mutations who developed severe autoimmune diseases such as colitis and autoimmune thyroiditis but no hypophysitis and hypopituitarism [76, 77].

The absence of pituitary abnormalities in these individuals supports the hypothesis that pituitary CTLA-4 expression is a significant factor which mediates hypophysitis. The high expression levels of CTLA-4 in a subset of pituitary adenomas raises the possibility that CTLA-4 may represent a novel direct therapeutic target for the treatment of aggressive pituitary tumors in selected patients [74]. Additionally, a chelated $64 \mathrm{Cu}$-isotope labeled anti-CTLA-4 Abs has recently been developed for use in positron emission tomography [78]. Thus, targeted imaging may be able to predict the risk of hypophysitis in patients treated with ipilimumab or possibly identify candidate patients with aggressive pituitary adenomas for therapeutic treatment with ipilimumab [78].

\section{Clinical Presentation and Natural History}

The clinical manifestations of immune checkpoint-induced hypophysitis are related either to structural or to hormonal disturbances [33]. Patients typically present with symptoms of sellar compression, such as headaches and visual field impairment, hypopituitarism, diabetes insipidus, and hyperprolactinemia [79]. Other symptoms that have been reported include confusion, hallucinations, memory loss, erectile dysfunction, dizziness, and insomnia $[17,42]$.
The role of anti-pituitary Abs in the diagnosis of autoimmune hypophysitis is debated, as positive anti-pituitary auto-Abs have been detected in $6-57 \%$ of patients with hypophysitis as well as in patients with other autoimmune diseases such as celiac disease and type 1 diabetes mellitus $[80,81]$. Recently, a new autoantigen, rabphilin-3A, has been identified as responsible for the autoimmune response in several patients with lymphocytic infundibuloneurohypophysitis [82].

Anti-CTLA-4 Abs-induced hypophysitis has been associated with pituitary function recovery in approximately $25 \%$ of cases only [42]. These data are in line with a recent study that followed patients with anti-CTLA-4-induced hypophysitis for over 2.5 years (median time of follow-up was 33.6 months) and found a long-term hormonal replacement requirement in $86.6 \%$ of patients [31]. In the same study, at initial diagnosis $73.3 \%$ of ipilimumab-treated patients presented with corticotroph, $86.6 \%$ with thyrotroph, and $85.6 \%$ with gonadotroph deficiency. Gonadotroph and thyrotroph deficiency persisted in $13 \%$ of patents during follow-up, whereas corticotroph deficiency persisted in almost all patients. This presentation is rather atypical compared to classical LYH where patients develop corticotroph deficiency in $32 \%$, $18 \%$ present with hyperprolactinemia, and $31 \%$ develop diabetes insipidus [4]. According to the authors, such particular features could lead to the hypothesis that ipilimumab-induced hypophysitis is a special entity [31]. However, the assessment of gonadotroph and thyrotroph function is more complicated in patients treated with anticancer agents, as it is difficult to determine whether there is a real improvement in hypophysitis or simple recovery from the underlying illness [28].

\section{Treatment}

Treatment of hypophysitis is focused in most cases on symptomatic management. In the acute phase, glucocorticoid replacement is mandatory and in some cases transsphenoidal surgery may be employed in patients with symptoms and/or signs of severe compression to nearby structures $[2,3]$. Other immunosuppressive drugs, including azathioprine, methotrexate, cyclosporine $\mathrm{A}$, and recently rituximab [83] and infliximab [21] have also been used successfully in corticosteroid-resistant cases, but data are scanty with these agents [1-3]. In the chronic phase, therapeutic strategy aims at the appropriate replacement therapy in cases of permanent pituitary deficiency.

Treatment of hypophysitis is influenced by the severity of symptoms and hormonal deficits in relation to the underlying malignancy. Concerning mild forms (grade 1) of
96

Neuroendocrinology 2018;106:89-100 DOI: $10.1159 / 000480086$
Angelousi/Chatzellis/Kaltsas 
immune checkpoint-related hypophysitis, continuation of immunotherapy and close observation are recommended [84]. For all other toxicity grades, it is recommended that ipilimumab be withheld and not resumed until the resolution of adverse events to grade 1 [83]. However, this recommendation has recently been debated following a large study suggesting continuation of immunotherapy with concomitant hormonal replacement [31]. The majority of experts agree that the clinical benefits of an anti-CTLA-4 treatment, such as ipilimumab in patients with potentially fatal malignancy, outweigh the risks of continuing therapy using an appropriate hormonal replacement therapy, although in an adjuvant setting the decision regarding treatment should be made after the patient has been fully informed of the risk of hypophysitis and corticotrophin deficiency that usually persists $[31,85]$.

For severe hypophysitis (grade 3 or 4), most authors use high-dose systemic steroids (prednisolone $1 \mathrm{mg} / \mathrm{kg} /$ day or equivalent) with sequential tapering to a physiological replacement dose of hydrocortisone or prednisolone $[30,43,83]$. However, the use of high-dose steroids did not alter the recovery of the pituitary function [31].

\section{Prevalence of Hypophysitis Related to Molecular Targeted Therapies}

Regarding molecular targeted agents such as everolimus and tyrosine kinase inhibitors (TKIs), data are scarce. Up to now, no cases of hypophysitis related to everolimus have been described $[14,86,87]$, and data on the effect of TKIs on pituitary function are under investigation. In particular, there are ongoing phase 3 (CheckMate 214) (ClinicalTrials.gov: NCT02231749) and phase 2 (ClinicalTrials.gov: NCT03075423) trials investigating the combination of nivolumab with ipilimumab versus sunitinib in subjects with metastatic renal cell carcinoma. A further phase 1 study (BMS-936558; MDX-1106) evaluates the combination of nivolumab with sunitinib, pazopanib, or ipilimumab in metastatic renal cell carcinoma (ClinicalTrials.gov: NCT01472081).

\section{Prevalence of Drug-Induced Hypophysitis and New Agents}

Currently, several ongoing clinical trials (ClinicalTrials.gov) are investigating new anti-CTLA-4 Abs or antiPD-1 Abs for malignant and nonmalignant diseases increasing the interest in the prevention of drug-induced

Hypophysitis Secondary to Biological

Therapies hypophysitis. Abatacept is a CTLA-4-Ig (BMS-188667) that is already used in a phase 2 study for prevention of type 1 diabetes in relatives of patients with type 1 diabetes (NCT01773707) as well as in other phase 1 and 2 studies including patients with systemic psoriasis (NCT00306878 and NCT00287547), granulomatosis with polyangiitis (Wegener's) (NCT02108860), and Takayashu arteritis, and in a phase 4 study including patients with primary biliary cirrhosis (NCT02078882). Another CTLA-4-Ig, belatacept, is included in trials for rheumatoid arthritis (NCT00279760). There are also combination protocols such as the association of tremelimumab with another anti-PD-L1 agent (MEDI4736) in colorectal cancer. Durvalumab is another new anti-PD-L1 agent currently tested in breast cancer patients in association with tremelimumab (NCT03132467). CX-072 is a Probody agent directed against $\mathrm{PD}-\mathrm{L} 1$ also tested in subjects with advanced or recurrent solid tumors or lymphomas (NCT03013491).

\section{Conclusions}

Better understanding of cancer biology has led to the development and wide use of novel immunomodulatory agents. Hypophysitis has emerged as a new specific side effect of treatment with anti-CTLA-4 Abs and particularly ipilimumab but is encountered less frequently with anti-PD-1 Abs. The pathophysiology of hypophysitis induced by these anticancer agents is not fully clarified, and the prevalence among the different studies varies widely. This is due to the heterogeneity of the studies regarding the design (phase 1, 2, 3), dose, follow-up (ranging between months to years), and treatment administered. Diagnosis of hypophysitis remains clinical since anti-pituitary Abs are not a sensitive marker, and thus its true prevalence is probably underestimated. Corticotroph, thyrotroph, and gonadotroph function seems to be the most affected, with thyrotroph and gonadotroph functions usually recovering during follow-up. However, particular attention needs to be paid to corticotroph function, which has a possible delayed onset and may not recover. The development of a method to evaluate tissue CTLA-4 expression prior to CTLA-4-targeted therapy is expected to allow treatment administration in line with evidencebased data, leading to cost-efficient medical care and avoidance of potential adverse effects. Therefore, as the use of these immunomodulatory agents is increasing, it is important for treating oncologists and endocrinologists to be aware of this association, allowing early identification and appropriate treatment of this side effect.

Neuroendocrinology 2018;106:89-100 97 


\section{References}

1 Caturegli P, Newschaffer C, Olivi A, Pomper MG, Burger PC, Rose NR: Autoimmune hypophysitis. Endocr Rev 2005;26:599-614.

2 Fukuoka H: Hypophysitis. Endocrinol Metab Clin North Am 2015;44:143-149.

3 Bellastella A, Bizzarro A, Coronella C, Bellastella G, Sinisi AA, De Bellis A: Lymphocytic hypophysitis: a rare or underestimated disease? Eur J Endocrinol 2003;149:363-376.

4 Caturegli P, Lupi I, Landek-Salgado M, Kimura H, Rose NR: Pituitary autoimmunity: 30 years later. Autoimmun Rev 2008;7:631-637.

5 Beressi N, Beressi JP, Cohen R, Modigliani E: Lymphocytic hypophysitis: a review of 145 cases. Ann Intern Med 1999;150:327-341.

6 Hashimoto K, Takao T, Makino S: Lymphocytic adenohypophysitis and lymphocytic infundibuloneurohypophysitis. Endocr J 1997; 44:1-10.

7 Molitch ME, Gillam MP: Lymphocytic hypophysitis. Horm Res 2007;68(suppl 5):145150.

8 Rivera JA: Lymphocytic hypophysitis: disease spectrum and approach to diagnosis and therapy. Pituitary 2006;9:35-45.

9 Falorni A, Minarelli V, Bartoloni E, Alunno A, Gerli R: Diagnosis and classification of autoimmune hypophysitis. Autoimmun Rev 2014;13:412-416.

10 Imber BS, Lee HS, Kunwar S, Blevins LS, Aghi MK: Hypophysitis: a single-center case series. Pituitary 2015;18:630-641.

11 Johnston PC, Chew LS, Hamrahian AH, Kennedy L: Lymphocytic infundibulo-neurohypophysitis: a clinical overview. Endocrine 2015;50:531-536.

12 Sakane N, Yoshida T, Yoshioka K, Umekawa T, Kondo M, Shimatsu A: Reversible hypopituitarism after interferon - a therapy. Lancet 1995;345:1305.

13 Concha LB, Carlson HE, Heimann A, LakeBakaar GV, Paal AF: Interferon-induced hypopituitarism. Am J Med 2003;114:161163.

14 Shang YH, Zhang Y, Li JH, Li P, Zhang X: Risk of endocrine adverse events in cancer patients treated with PD-1 inhibitors: a systematic review and meta-analysis. Immunotherapy 2017;9:261-272.

15 Abdel-Rahman O, El Halawani H, Fouad M: Risk of endocrine complications in cancer patients treated with immune check point inhibitors: a meta-analysis. Future Oncol 2016; 12:413-425.

16 Corsello SM, Barnabei A, Marchetti P, De Vecchis L, Salvatori R, Torino F: Endocrine side effects induced by immune checkpoint inhibitors. J Clin Endocrinol Metab 2013;98: 1361-1375.

17 Torino F, Barnabei A, Paragliola RM, Marchetti P, Salvatori R, Corsello SM: Endocrine side-effects of anti-cancer drugs: mAbs and pituitary dysfunction: clinical evidence and pathogenic hypotheses. Eur J Endocrinol 2013;169:153-164.
18 Ridruejo E, Christensen AF, Mando OG: Central hypothyroidism and hypophysitis during treatment of chronic hepatitis $\mathrm{C}$ with pegylated interferon alpha and ribavirin. Eur J Gastroenterol Hepatol 2006;18:693-694.

19 Tebben PJ, Atkinson JL, Scheithauer BW, Erickson D: Granulomatous adenohypophysitis after interferon and ribavirin therapy. Endocr Pract 2007;13:169-175.

20 Chan WB, Cockram CS: Panhypopituitarism in association with interferon-alpha treatment. Singap Med J 2004;45:93-94.

21 Straub RH, Pongratz G, Schölmerich J, Kees F, Schaible TF, Antoni C, Kalden JR, Lorenz HM: Long-term anti-tumor necrosis factor antibody therapy in rheumatoid arthritis patients sensitizes the pituitary gland and favors adrenal androgen secretion. Arthritis Rheum 2003;48:1504-1512.

$22 \mathrm{Xu}$ C, Ricciuti A, Caturegli P, Keene CD, Kargi AY: Autoimmune lymphocytic hypophysitis in association with autoimmune eye disease and sequential treatment with infliximab and rituximab. Pituitary 2015;18:441-447.

23 Thompson CB, Allison JP: The emerging role of CTLA- 4 as an immune attenuator. Immunity 1997;7:445-450.

24 Vidarsson G, Dekkers G, Rispens T: IgG subclasses and allotypes: from structure to effector functions. Front Immunol 2014;5:520.

25 Hodi FS, O'Day SJ, McDermott DF, Weber RW, Sosman JA, Haanen JB, Gonzalez R, Robert C, Schadendorf D, Hassel JC, Akerley W, van den Eertwegh AJ, Lutzky J, Lorigan P, Vaubel JM, Linette GP, Hogg D, Ottensmeier CH, Lebbé C, Peschel C, Quirt I, Clark JI, Wolchok JD, Weber JS, Tian J, Yellin MJ, Nichol GM, Hoos A, Urba WJ: Improved survival with ipilimumab in patients with metastatic melanoma. N Engl J Med 2010;363:711723.

26 Horvat TZ, Adel NG, Dang TO, Momtaz P, Postow MA, Callahan MK, Carvajal RD, Dickson MA, D'Angelo SP, Woo KM, Panageas KS, Wolchok JD, Chapman PB: Immune-related adverse events, need for systemic immunosuppression, and effects on survival and time to treatment failure in patients with melanoma treated with ipilimum$\mathrm{ab}$ at Memorial Sloan Kettering Cancer Center. J Clin Oncol 2015;33:3193-3198.

27 Eggermont AM, Chiarion-Sileni V, Grob JJ, Dummer R, Wolchok JD, Schmidt H,Hamid O, Robert C, Ascierto PA, Richards JM, Lebbé C, Ferraresi V, Smylie M, Weber JS, Maio M, Konto C, Hoos A, de Pril V, Gurunath RK, de Schaetzen G, Suciu S, Testori A: Adjuvant ipilimumab versus placebo after complete resection of high-risk stage III melanoma (EORTC 18071): a randomised, double-blind, phase 3 trial. Lancet Oncol 2015;16:522-530.

28 Ryder M, Callahan M, Postow MA Wolchok J, Fagin JA: Endocrine-related adverse events following ipilimumab in patients with advanced melanoma: a comprehensive retro- spective review from a single institution. Endocr Relat Cancer 2014;21:371-381.

29 Min L, Hodi FS, Giobbie-Hurder A, Ott PA, Luke JJ, Donahue H, Davis M, Carroll RS, Kaiser UB: Systemic high-dose corticosteroid treatment does not improve the outcome of ipilimumab-related hypophysitis: a retrospective cohort study. Clin Cancer Res 2015; 21:749-755.

30 Faje AT, Sullivan R, Lawrence D, Tritos NA, Fadden R, Klibanski A, Nachtigall L: Ipilimumab-induced hypophysitis: a detailed longitudinal analysis in a large cohort of patients with metastatic melanoma. J Clin Endocrinol Metab 2014;99:4078-4085.

31 Albarel F, Gaudy C, Castinetti F, Carré T, Morange I, Conte-Devolx B, Grob JJ, Brue T: Long-term follow-up of ipilimumab-induced hypophysitis, a common adverse event of the anti-CTLA-4 antibody in melanoma. Eur J Endocrinol 2015;172:195-204.

32 Maker AV, Yang JC, Sherry RM, Topalian SL, Kammula US, Royal RE, Hughes M, Yellin MJ, Haworth LR, Levy C, Allen T, Mavroukakis SA, Attia P, Rosenberg SA: Intra-patient dose escalation of anti-CTLA- 4 antibody in patients with metastatic melanoma. J Immunother 2006;29:455-463.

33 Blansfield JA, Beck KE, Tran K, Yang JC, Hughes MS, Kammula US, Royal RE, Topalian SL, Haworth LR, Levy C, Rosenberg SA, Sherry RM: Cytotoxic T-lymphocyte-associated antigen- 4 blockage can induce autoimmune hypophysitis in patients with metastatic melanoma and renal cancer. J Immunother 2005;28:593-598.

34 Royal RE, Levy C, Turner K, Mathur A, Hughes M, Kammula US, Sherry RM, Topalian SL, Yang JC, Lowy I, Rosenberg SA: Phase 2 trial of single agent ipilimumab (anti-CTLA-4) for locally advanced or metastatic pancreatic adenocarcinoma. J Immunother 2010; 33:828-833.

35 Yang JC, Hughes M, Kammula U, Royal R, Sherry RM, Topalian SL, Suri KB, Levy C, Allen T, Mavroukakis S, Lowy I, White DE, Rosenberg SA: Ipilimumab (anti-CTLA-4 antibody) causes regression of metastatic renal cell cancer associated with enteritis and hypophysitis. J Immunother 2007;30:825-830.

36 Ansell SM, Hurvitz SA, Koenig PA, LaPlant BR, Kabat BF, Fernando D, Habermann TM, Inwards DJ, Verma M, Yamada R, Erlichman C, Lowy I, Timmerman JM: Phase I study of ipilimumab, an anti-CTLA-4 monoclonal antibody, in patients with relapsed and refractory B cell non-Hodgkin lymphoma. Clin Cancer Res 2009; 15:6446-6453.

37 Ku GY, Yuan J, Page DB, Schroeder SE, Panageas KS, Carvajal RD, Chapman PB, Schwartz GK, Allison JP, Wolchok JD: Single-institution experience with ipilimumab in advanced melanoma patients in the compassionate use setting: lymphocyte count after 2 doses correlates with survival. Cancer 2010;116:1767-1775. 
38 Kirkwood JM, Lorigan P, Hersey P, Hauschild A, Robert C, McDermott D, Marshall MA, Gomez-Navarro J, Liang JQ, Bulanhagui CA: Phase II trial of tremelimumab (CP-675,206) in patients with advanced refractory or relapsed melanoma. Clin Cancer Res 2010;16: 1042-1048.

39 Ribas A, Kefford R, Marshall MA, Punt CJ, Haanen JB, Marmol M, Garbe C, Gogas H, Schachter J, Linette G, Lorigan P, Kendra KL, Maio M, Trefzer U, Smylie M, McArthur GA, Dreno B, Nathan PD, Mackiewicz J, Kirkwood JM, Gomez-Navarro J, Huang B, Pavlov D, Hauschild A: Phase III randomized clinical trial comparing tremelimumab with standard-ofcare chemotherapy in patients with advanced melanoma. J Clin Oncol 2013;31:616-622.

40 Ribas A, Camacho LH, Lopez-Berestein G, Pavlov D, Bulanhagui CA, Millham R, Comin-Anduix B, Reuben JM, Seja E, Parker CA, Sharma A, Glaspy JA, Gomez-Navarro J: Antitumor activity in melanoma and anti-self responses in a phase I trial with the anti-cytotoxic $\mathrm{T}$ lymphocyte-associated antigen 4 monoclonal antibody. J Clin Oncol 2005;23: 8968-8977.

41 Wolchok JD, Neyns B, Linette G, Negrier S, Lutzky J, Thomas L, Waterfield W, Schadendorf D, Smylie M, Guthrie T Jr, Grob JJ, Chesney J, Chin K, Chen K, Hoos A, O’Day SJ, Lebbé C: Ipilimumab monotherapy in patients with pretreated advanced melanoma: a randomised, double-blind, multicentre, phase 2, dose-ranging study. Lancet Oncol 2010;11:155-164.

42 Bertrand A, Kostine M, Barnetche T, Truchetet ME, Schaeverbeke T: Immune related adverse events associated with anti-CTLA- 4 antibodies: systematic review and meta-analysis. BMC Med 2015;13:211.

43 Juszczak A, Gupta A, Karavitaki N, Middleton $\mathrm{MR}$, Grossman AB: Ipilimumab: a novel immunomodulating therapy causing autoimmune hypophysitis: a case report and review. Eur J Endocrinol 2012;167:1-5.

44 Wolchok JD, Kluger H, Callahan MK, Postow MA, Rizvi NA, Lesokhin AM, Segal NH, Ariyan CE, Gordon RA, Reed K, Burke MM, Caldwell A, Kronenberg SA, Agunwamba BU, Zhang X, Lowy I, Inzunza HD, Feely W, Horak CE, Hong Q, Korman AJ, Wigginton JM, Gupta A, Sznol M: Nivolumab plus ipilimumab in advanced melanoma. $\mathrm{N}$ Engl J Med 2013;369:122-133.

45 Topalian SL, Hodi FS, Brahmer JR, Gettinger SN, Smith DC, McDermott DF, Powderly JD, Carvajal RD, Sosman JA, Atkins MB, Leming PD, Spigel DR, Antonia SJ, Horn L, Drake CG, Pardoll DM, Chen L, Sharfman WH, Anders RA, Taube JM, McMiller TL, Xu H, Korman AJ, Jure-Kunkel M, Agrawal S, McDonald D, Kollia GD, Gupta A, Wigginton JM, Sznol M: Safety, activity, and immune correlates of anti-PD-1 antibody in cancer. N Engl J Med 2012;366:2443-2454.

46 Ribas A, Puzanov I, Dummer R, Schadendorf D, Hamid O, Robert C, Hodi FS, Schachter J, Pavlick AC, Lewis KD, Cranmer LD, Blank CU,
O’Day SJ, Ascierto PA, Salama AK, Margolin KA, Loquai C, Eigentler TK, Gangadhar TC, Carlino MS, Agarwala SS, Moschos SJ, Sosman JA, Goldinger SM, Shapira-Frommer R, Gonzalez R, Kirkwood JM, Wolchok JD, Eggermont A, Li XN, Zhou W, Zernhelt AM, Lis J, Ebbinghaus S, Kang SP, Daud A: Pembrolizumab versus investigator-choice chemotherapy for ipilimumab-refractory melanoma (KEYNOTE-002): a randomised, controlled, phase 2 trial. Lancet Oncol 2015;16:908-918.

47 Herbst RS, Baas P, Kim DW, Felip E, PérezGracia JL, Han JY, Molina J, Kim JH, Arvis CD, Ahn MJ, Majem M, Fidler MJ, de Castro G Jr, Garrido M, Lubiniecki GM, Shentu Y, Im E, Dolled-Filhart M, Garon EB: Pembrolizumab versus docetaxel for previously treated, PD-L1-positive, advanced non-small-cell lung cancer (KEYNOTE-010): a randomised controlled trial. Lancet 2016;387:1540-1550.

48 Robert C, Ribas A, Wolchok JD, Hodi FS, Hamid O, Kefford R, Weber JS, Joshua AM, Hwu WJ, Gangadhar TC, Patnaik A, Dronca R, Zarour H, Joseph RW, Boasberg P, Chmielowski B, Mateus C, Postow MA, Gergich K, Elassaiss-Schaap J, Li XN, Iannone R, Ebbinghaus SW, Kang SP, Daud A: Anti-programmeddeath-receptor-1 treatment with pembrolizumab in ipilimumab-refractory advanced melanoma: a randomized dose-comparison cohort of a phase 1 trial. Lancet 2014;384: 1109-1117.

49 Robert C, Schachter J, Long GV, Arance A, Grob JJ, Mortier L, Daud A, Carlino MS, McNeil C, Lotem M, Larkin J, Lorigan P, Neyns B, Blank CU, Hamid O, Mateus C, ShapiraFrommer R, Kosh M, Zhou H, Ibrahim N, Ebbinghaus S, Ribas A: Pembrolizumab versus ipilimumab in advanced melanoma. $\mathrm{N}$ Engl J Med 2015;372:2521-2532.

50 Ribas A, Hamid O, Daud A, Hodi FS, Wolchok JD, Kefford R, Joshua AM, Patnaik A, Hwu WJ, Weber JS, Gangadhar TC, Hersey P, Dronca R, Joseph RW, Zarour H, Chmielowski B, Lawrence DP, Algazi A, Rizvi NA, Hoffner B, Mateus C, Gergich K, Lindia JA, Giannotti M, Li XN, Ebbinghaus S, Kang SP, Robert C: Association of pembrolizumab with tumor response and survival among patients with advanced melanoma. JAMA 2016;315: 1600-1609.

51 Le DT, Uram JN, Wang H, Bartlett BR, Kemberling $\mathrm{H}$, Eyring $\mathrm{AD}$, Skora $\mathrm{AD}$, Luber BS, Azad NS, Laheru D, Biedrzycki B, Donehower RC, Zaheer A, Fisher GA, Crocenzi TS, Lee JJ, Duffy SM, Goldberg RM, de la Chapelle A, Koshiji M, Bhaijee F, Huebner T, Hruban RH, Wood LD, Cuka N, Pardoll DM, Papadopoulos N, Kinzler KW, Zhou S, Cornish TC, Taube JM, Anders RA, Eshleman JR, Vogelstein B, Diaz LA Jr: PD-1 Blockade in Tumors with Mismatch-Repair Deficiency. N Engl J Med 2015;372:2509-2520.

52 Topalian, SL, Topalian SL, Sznol M, McDermott DF, Kluger HM, Carvajal RD, Sharfman WH, Brahmer JR, Lawrence DP, Atkins MB, Powderly JD, Leming PD, Lipson EJ, Puzanov
I, Smith DC, Taube JM, Wigginton JM, Kollia GD, Gupta A, Pardoll DM, Sosman JA, Hodi FS: Survival, durable tumor remission, and long-term safety in patients with advanced melanoma receiving nivolumab. J Clin Oncol 2014;32:1020-1030.

53 Costa R, Carneiro BA, Agulnik M, Rademaker AW, Pai SG, Villaflor VM, Cristofanilli M, Sosman JA, Giles FJ: Toxicity profile of approved anti-PD-1 monoclonal antibodies in solid tumors: a systematic review and metaanalysis of randomized clinical trials. Oncotarget 2017;8:8910-8920.

54 McDermott, DF, Sosman JA, Sznol M, Massard C, Gordon MS, Hamid O, Powderly JD, Infante JR, Fassò M, Wang YV, Zou W, Hegde PS, Fine GD, Powles T: Atezolizumab, an anti-programmed death-ligand 1 antibody, in metastatic renal cell carcinoma: long-term safety, clinical activity, and immune correlates from a phase I a study. J Clin Oncol 2016; 34:833-842.

55 Gay CL, Bosch RJ, Ritz J, Hataye JM, Aga E, Tressler RL, Mason SW, Hwang CK, Grasela DM, Ray N, Cyktor JC, Coffin JM, Acosta EP, Koup RA, Mellors JW, Eron JJ; AIDS Clinical Trials 5326 Study Team: Clinical trial of the anti-PD-L1 antibody BMS-936559 in HIV-1 infected participants on suppressive antiretroviral therapy. Infect Dis 2017;215:1725-1733.

56 Madan RA, Mohebtash M, Arlen PM, Vergati M, Rauckhorst M, Steinberg SM, Tsang KY, Poole DJ, Parnes HL, Wright JJ, Dahut WL, Schlom J, Gulley JL: Ipilimumab and a poxviral vaccine targeting prostate-specific antigen in metastatic castration-resistant prostate cancer: a phase 1 dose-escalation trial. Lancet Oncol 2012;13:501-508.

57 van den Eertwegh AJ, Versluis J, van den Berg HP, Santegoets SJ, van Moorselaar RJ, van der Sluis TM, Gall HE, Harding TC, Jooss K, Lowy I, Pinedo HM, Scheper RJ, Stam AG, von Blomberg BM, de Gruijl TD, Hege $\mathrm{K}$, Sacks N, Gerritsen W: Combined immunotherapy with granulocyte-macrophage colony-stimulating factor-transduced allogeneic prostate cancer cells and ipilimumab in patients with metastatic castration-resistant prostate cancer: a phase 1 dose-escalation trial. Lancet Oncol 2012;13:509-517.

58 Hodi FS, Lawrence D, Lezcano C, Wu X, Zhou J, Sasada T, Zeng W, Giobbie-Hurder A, Atkins MB, Ibrahim N, Friedlander P, Flaherty KT, Murphy GF, Rodig S, Velazquez EF, Mihm MC Jr, Russell S, DiPiro PJ, Yap JT, Ramaiya N, Van den Abbeele AD, Gargano M, McDermott D: Bevacizumab plus ipilimumab in patients with metastatic melanoma. Cancer Immunol Res 2014;2:632-642.

59 Hodi FS, Friedlander PA, Atkins MB, McDermott DF, Lawrence DP, Ibrahim N, Zhou X, Wu, J, Giobbie-Hurder A, Murphy G, Hollman T, Velazquez E, Russell S, Dipiro P, Yap JT, Van Den Abbeele AD: A phase I trial of ipilimumab plus bevacizumab in patients with unresectable stage III or stage IV melanoma (abstract). J Clin Oncol 2011;29:8511. 
60 Larkin J, Chiarion-Sileni V, Gonzalez R, Grob JJ, Cowey CL, Lao CD, Schadendorf D, Dummer R, Smylie M, Rutkowski P, Ferrucci PF, Hill A, Wagstaff J, Carlino MS, Haanen JB, Maio M, Marquez-Rodas I, McArthur GA, Ascierto PA, Long GV, Callahan MK, Postow MA, Grossmann K, Sznol M, Dreno B, Bastholt L, Yang A, Rollin LM, Horak C, Hodi FS, Wolchok JD: Combined nivolumab and ipilimumab or monotherapy in untreated melanoma. N Engl J Med 2015;373:23-34.

61 Postow MA, Chesney J, Pavlick AC, Robert C, Grossmann K, McDermott D, Linette GP, Meyer N, Giguere JK, Agarwala SS, Shaheen M, Ernstoff MS, Minor D, Salama AK, Taylor M, Ott PA, Rollin LM, Horak C, Gagnier P, Wolchok JD, Hodi FS: Nivolumab and ipilimumab versus ipilimumab in untreated melanoma. N Engl J Med 2015;372:2006-2017.

62 Lynch TJ, Bondarenko I, Luft A, Serwatowski P, Barlesi F, Chacko R, Sebastian M, Neal J, Lu $\mathrm{H}$, Cuillerot JM, Reck M: Ipilimumab in combination with paclitaxel and carboplatin as first-line treatment in stage IIIB/IV nonsmall-cell lung cancer: results from a randomized, double-blind, multicenter phase II study. J Clin Oncol 2012;30:2046-2054.

63 Di Giacomo AM, Ascierto PA, Pilla L, Santinami M, Ferrucci PF, Giannarelli D, Marasco A, Rivoltini L, Simeone E, Nicoletti SV, Fonsatti E, Annesi D, Queirolo P, Testori A, Ridolfi R, Parmiani G, Maio M: Ipilimumab and fotemustine in patients with advanced melanoma (NIBIT-M1): an open-label, single-arm phase 2 trial. Lancet Oncol 2012;13: 879-886.

64 Haanen JB, van Thienen HV, Blank CU: Toxicity patterns with immunomodulating antibodies and their combinations. Semin Oncol 2015;42:423.

65 Iwama S, De Remigis A, Callahan MK, Slovin SF, Wolchok JD, Caturegli P: Pituitary expression of CTLA-4 mediates hypophysitis secondary to administration of CTLA-4 blocking antibody. Sci Transl Med 2014;6: 230.

66 Joshi MN, Whitelaw BC, Palomar MT, Wu Y, Carroll PV: Immune checkpoint inhibitorrelated hypophysitis and endocrine dysfunction: clinical review. Clin Endocrinol 2016;85: 331-339.

67 Laurent S, Queirolo P, Boero S, Salvi S, Piccioli P, Boccardo S, Minghelli S, Morabito A, Fontana V, Pietra G, Carrega P, Ferrari N, Tosetti F, Chang LJ, Mingari MC, Ferlazzo G, Poggi A, Pistillo MP: The engagement of CTLA-4 on primary melanoma cell lines induces antibody-dependent cellular cytotoxicity and TNF- $\alpha$ production. J Transl Med 2013; 11:108.

68 Romano E, Kusio-Kobialka M, Foukas PG, Baumgaertner P, Meyer C, Ballabeni P, Michielin O, Weide B, Romero P, Speiser DE: Ipilimumab-dependent cell-mediated cytotoxicity of regulatory $\mathrm{T}$ cells ex vivo by nonclassical monocytes in melanoma patients. Proc Natl Acad Sci USA 2015;112:6140-6145.
69 Sharma P, Wagner K, Wolchok JD, Allison JP: Novel cancer immunotherapy agents with survival benefit: recent successes and next steps. Nat Rev Cancer 2011;11:805-812.

70 Byun DJ, Wolchok JD, Rosenberg LM, Girotra M: Cancer immunotherapy - immune checkpoint blockade and associated endocrinopathies. Nat Rev Endocrinol 2017;13:195207.

71 Chow LQ: Exploring novel immune-related toxicities and endpoints with immune-checkpoint inhibitors in non-small cell lung cancer. Am Soc Clin Oncol Educ DOI: 10.1200/EdBook_AM.2013.33.e280.

72 Brahmer JR, Tykodi SS, Chow LQ, Hwu WJ, Topalian SL, Hwu P, Drake CG, Camacho LH, Kauh J, Odunsi K, Pitot HC, Hamid O, Bhatia S, Martins R, Eaton K, Chen S, Salay TM, Alaparthy S, Grosso JF, Korman AJ, Parker SM, Agrawal S, Goldberg SM, Pardoll DM, Gupta A, Wigginton JM: Safety and activity of anti-PD-L1 antibody in patients with advanced cancer. N Engl J Med 2012;366: 2455-2465.

73 Messal N, Serriari NE, Pastor S, Nunes JA, Olive $\mathrm{D}$ : $\mathrm{PD}-\mathrm{L} 2$ is expressed on activated human $\mathrm{T}$ cells and regulates their function. Mol Immunol 2011;48:2214-2219.

74 Faje A: Immunotherapy and hypophysitis: clinical presentation, treatment, and biologic insights. Pituitary 2016;19:82-92.

75 Snyder A, Makarov V, Merghoub T, Yuan J, Zaretsky JM, Desrichard A, Walsh LA, Postow MA, Wong P, Ho TS, Hollmann TJ, Bruggeman C, Kannan K, Li Y, Elipenahli C, Liu C, Harbison CT, Wang L, Ribas A, Wolchok JD, Chan TA: Genetic basis for clinical response to CTLA-4 blockade in melanoma. N Engl J Med 2014;371:2189-2199.

76 Kuehn HS, Ouyang W, Lo B, Deenick EK, Niemela JE, Avery DT, Schickel JN, Tran DQ, Stoddard J, Zhang Y, Frucht DM, Dumitriu B, Scheinberg P, Folio LR, Frein CA, Price S, Koh C, Heller T, Seroogy CM, Huttenlocher A, Rao VK, Su HC, Kleiner D, Notarangelo LD, Rampertaap Y, Olivier KN, McElwee J, Hughes J, Pittaluga S, Oliveira JB, Meffre E, Fleisher TA, Holland SM, Lenardo MJ, Tangye SG, Uzel G: Immune dysregulation in human subjects with heterozygous germline mutations in CTLA4. Science 2014;345:16231627.

77 Schubert D, Bode C, Kenefeck R, Hou TZ, Wing JB, Kennedy A, Bulashevska A, Petersen BS, Schaffer AA, Gruning BA, Unger S, Frede N, Baumann U, Witte T, Schmidt RE, Dueckers G, Niehues T, Seneviratne S, Kanariou M, Speckmann C, Ehl S, Rensing-Ehl A, Warnatz K, Rakhmanov M, Thimme R, Hasselblatt P, Emmerich F, Cathomen T, Backofen R, Fisch P, Seidl M, May A, SchmittGraeff A, Ikemizu S, Salzer U, Franke A, Sakaguchi S, Walker LS, Sansom DM, Grimbacher B: Autosomal dominant immune dysregulation syndrome in humans with CTLA4 mutations. Nat Med 2014;20:1410-1416.
78 Higashikawa K, Yagi K, Watanabe K, Kamino $S$, Ueda M, Hiromura M, Enomoto S: $64 \mathrm{Cu}-$ DOTA-anti-CTLA-4 mAb enabled PET visualization of CTLA-4 on the T-cell infiltrating tumor tissues. PLoS One 2014;9:e109866.

79 Dillard T, Yedinak CG, Alumkal J, Fleseriu M: Anti-CTLA-4 antibody therapy associated autoimmune hypophysitis: serious immune related adverse events across a spectrum of cancer subtypes. Pituitary 2010;13:29-38.

80 Hamnvik OP, Laury AR, Laws ER Jr, Kaiser UB: Lymphocytic hypophysitis with diabetes insipidus in a young man. Nat Rev Endocrinol 2010;6:464-470.

81 Delvecchio M, De Bellis A, Francavilla R, Rutigliano V, Predieri B, Indrio F, De Venuto D, Sinisi AA, Bizzarro A, Bellastella A, Iughetti L, Cavallo L: Italian Autoimmune Hypophysitis Network Study. Anti-pituitary antibodies in children with newly diagnosed celiac disease: a novel finding contributing to lineargrowth impairment. Am J Gastroenterol 2010;105:691-696.

82 Iwama S, Sugimura Y, Kiyota A, Kato T, Enomoto A, Suzuki H, Iwata N, Takeuchi S, Nakashima K, Takagi H, Izumida H, Ochiai H, Fujisawa $H$, Suga $H$, Arima $H$, Shimoyama $Y$, Takahashi M, Nishioka H, Ishikawa SE, Shimatsu A, Caturegli P, Oiso Y: Rabphilin-3A as a targeted autoantigen in lymphocytic infundibulo-neurohypophysitis. J Clin Endocrinol Metab 2015;100:946-954.

83 Schreckinger M, Francis T, Rajah G, Jagannathan J, Guthikonda M, Mittal S: Novel strategy to treat a case of recurrent lymphocytic hypophysitis using rituximab. J Neurosurg 2012;116:1318-1323.

84 Marlier J, Cocquyt V, Brochez L, Van Belle S, Kruse V: Ipilimumab, not just another anticancer therapy: hypophysitis as side effect illustrated by four case-reports. Endocrine 2014;47:878-883.

85 Torino F, Barnabei A, Paragliola RM, Marchetti P, Salvatori R, Corsello SM: Endocrine side-effects of anti-cancer drugs: $\mathrm{mAbs}$ and pituitary dysfunction: clinical evidence and pathogenic hypotheses. Eur J Endocrinol 2013;169:153-164.

86 Tomita Y, Fukasawa S, Shinohara N, Kitamura $\mathrm{H}$, Oya M, Eto M, Tanabe K, Kimura G, Yonese J, Yao $\mathrm{M}$, Motzer RJ, Uemura $\mathrm{H}$, McHenry MB, Berghorn E, Ozono S: Nivolumab versus everolimus in advanced renal cell carcinoma: Japanese subgroup analysis from the CheckMate 025 study. J Clin Oncol 2017;13:1-8.

87 Motzer RJ, Escudier B, McDermott DF, George S, Hammers HJ, Srinivas S, Tykodi SS, Sosman JA, Procopio G, Plimack ER, Castellano D, Choueiri TK, Gurney H, Donskov F, Bono P, Wagstaff J, Gauler TC, Ueda T, Tomita Y, Schutz FA, Kollmannsberger C, Larkin J, Ravaud A, Simon JS, Xu LA, Waxman IM, Sharma P: CheckMate 025 Investigators. Nivolumab versus everolimus in advanced renal-cell carcinoma. N Engl J Med 2015;373: 1803-1183. 